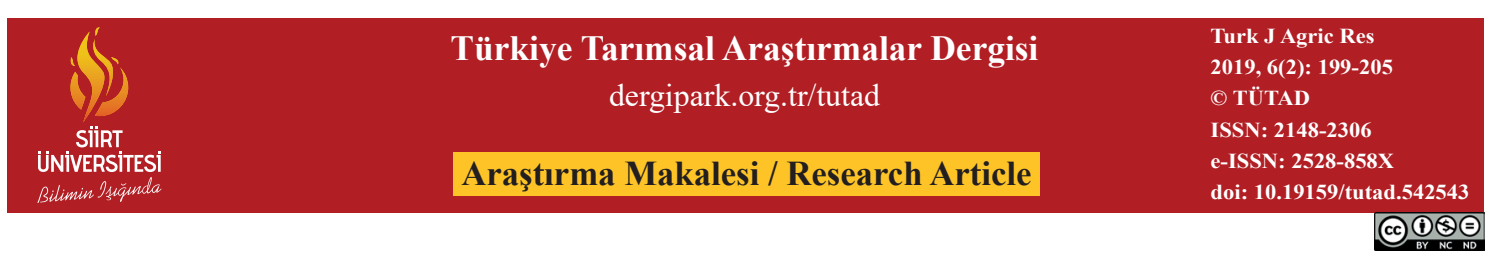

\title{
Bazı Arazi ve Toprak Niteliklerinin Coğrafi Bilgi Sistem Analizleriyle İncelenmesi: Van İli Arazi ve Toprak Özellikleri
}

\author{
Siyami KARACA ${ }^{1 *}$, Bulut SARĞIN ${ }^{1}$, Ferhat TÜRKMEN ${ }^{2}$ \\ ${ }^{1}$ Van Yüzüncü Yıl Üniversitesi, Ziraat Fakültesi, Toprak Bilimi ve Bitki Besleme Bölümü, Van, TÜRKIYYE \\ ${ }^{2}$ Ordu Üniversitesi, Ziraat Fakültesi, Toprak Bilimi ve Bitki Besleme Bölümü, Ordu, TÜRKIYYE
}

\begin{tabular}{|c|c|}
\hline Geliş Tarihi/Received: 20.03.2019 & Kabul Tarihi/Accepted: 30.06 .2019 \\
\hline \multicolumn{2}{|c|}{ ORCID ID (Yazar surasına göre / by author order) } \\
\hline \multicolumn{2}{|c|}{ (D) orcid.org/0000-0002-2434-1171 (DD) orcid.org/0000-0002-4752-4333 (D)orcid.org/0000-0003-3418-8083 } \\
\hline
\end{tabular}

Öz: Bu çalışmada; Coğrafi Bilgi Sistemleri (CBS) kullanılarak Türkiye'nin Doğu Anadolu Bölgesi'nde yer alan Van ilinin, bazı arazi ve toprak özelliklerinin tespiti ile veri tabanının oluşturulması amaçlanmıştır. Çalışılan alan 2.075 .900 hektardır. Araştırmada, (Mülga) Köy Hizmetleri Genel Müdürlüğü tarafından oluşturulan veriler kullanılarak, CBS ortamında il toprak özellikleri belirlenerek haritalanmıştır. Çalışmada ilk olarak Van ilinin topoğrafik haritasından arazinin yükselti modeli elde edilmiștir. Elde edilen modelin kullanılmasıyla, eğim, bakı, yükselti ve kabartı haritaları olușturulmuștur. Çalıșma sonucuna göre; Van ilinin toplam alanın \% 24.63'ü \% 6'dan düşük eğim değerlerine sahip iken, \% 40.53'ü ise \% 6-30 arasındaki eğim değerlerine sahip olup, \% 30'un altında bulunan eğimli alanlar ilin \% 64.16'sında görülmektedir. Van ilinde çoğunlukla görülen büyük toprak grubu, \% 49.21 oranıla kestane rengi topraklardır. Bu grubu sırasıyla \% 15.62 oranıly kireçsiz kahverengi topraklar ile \% 13.00 oranıyla kahverengi topraklar izlemektedir. Arazi kullanım haritası incelendiğinde, çalıșma alanının \% 61.03'lük bölümünü meralık, \% 14.55'lik bölümünü kuru tarım arazileri kapsamaktadır. Çalışma alanının \% 77.20 'sinin orta, şiddetli ve çok şiddetli erozyon sınıflarına sahip olduğu ve alanın \% 16.39'luk kısmını I., II. ve III. sınıf arazilerin teşkil ettiği belirlenmiştir. Toprak derinliği bakımından, incelenen alanın \% 23.71'lik kısmının çok sığ ve sığ toprak özelliğine sahip olduğu tespit edilmiştir.

Anahtar Kelimeler: Arazi, toprak, coğrafi bilgi sistemleri, Van

\section{Investigation of Some Land and Soil Properties by Geographical Information System Analysis: Van Province Land and Soil Properties}

\begin{abstract}
In this study, some land and soil characteristics of Van province, located in Turkey's Eastern Anatolia Region, are intended to be identified, using Geographic Information Systems (GIS) with the creation of the database. The studied area is 2.075.900 hectares. In this research, provincial soil characteristics were determined and mapped by using data created by General Directorate of Rural Services (Mülga). In the study, first elevation model of the land was obtained from the topographic map of Van province. Using the obtained model, slope, aspect, elevation and relief maps were created. According to the results of the study, while $24.63 \%$ of the total area of Van had slope values less than $6 \%, 40.53 \%$ had slope values between $6-30 \%$. Sloping areas below $30 \%$ are seen in $64.16 \%$ of the province. The largest group of soils in the province of Van are chestnut soils with a ratio of $49.21 \%$. This group is followed by lime-free brown soils with a ratio of $15.62 \%$ and brown soils with a ratio of $13.00 \%$. When the land use map is examined, $61.03 \%$ of the study area consists of pasture and $14.55 \%$ of it covers dry agricultural land. It was determined that $77.20 \%$ of the study area had moderate, severe and very severe erosion classes. $16.39 \%$ of the study area consists of I., II. and III. class land areas. In terms of soil depth, it was determined that $23.71 \%$ of the area had very shallow and shallow soil characteristics.
\end{abstract}

Keywords: Land, soil, geographical information systems, Van 


\section{Giriş}

Sınırlı yeryüzü kaynaklarının ve hızı nüfus artışının etkisi ile insanların isteklerini karşılamada doğal kaynaklar yetersiz kalmıştır. Bundan nedenle doğal kaynakların akılcı ve yerine göre kullanılması çok önemlidir. Tarım arazilerinin sürdürülebilirliği ve arazilerde çalışma faaliyetlerinin tasarlanıp hayata geçirilmesi gün geçtikçe artan bir şekilde kıymet kazanmaktadır. Bundan dolayı, verileri devamlı değişmekte olan toprak kaynaklarının belirlenmesi ve verilerin güncelleme çalışmalarının devamlı olması gerektirmektedir. Tarımsal üretimde alt yapıyı sağlayan toprağın daha etkili ve sürdürülebilir şekilde kullanılması için, toprağın öz niteliklerinin bilinmesi önemli bir husustur.

Türkiye topraklarının niteliklerinin tespiti ve arazi kaynaklarının etkili ve yerinde kullanılması, ülke tarımına yön verilmesinde önemli bir zorunluluktur. Elde edilen tespitler ve değerlendirmeler sonucunda, arazilerin ve doğal kaynakların; daha etkili, daha uygun ve daha verimli kullanılması için Coğrafi Bilgi Sistemleri (CBS)'nden faydalanılması gerekmektedir. Coğrafi Bilgi Sistemleri'nin kullanımı, tarım alanlarının aşırı kullanımdan doğabilecek sorunların minimize edilmesini sağlayabilir ve birim alandan maksimum verimin elde edilmesine yardımcı olabilir. Arazi varlığı ve temel özellikleri ile ilgili sağlıklı bir envanterin elde edilmesiyle mevcut kaynaklar üzerinde yapılacak planlamalar etkili bir yap1 üzerine inşa edileceğinden, üretim girdileri azalırken, elde edilecek çıktılar artacaktır (Akgül ve Başayiğit, 2005; Özyazıcı ve ark., 2015, 2016). Bu doğrultuda yapilacak toprak etüt ve haritalandırma çalışmaları büyük önem taşımaktadır. Planlama öncesi arazi varlığının nitelik ve nicelik yapılarının ortaya konulması, kaynakların potansiyelinin belirlenmesi, yeni teknolojiler doğrultusunda veri tabanının ve haritaların düzenlenmesine ihtiyaç duyulmaktadır (Dengiz ve Sarığlu, 2011a, 2011b; Özyazıcı ve ark., 2014).

Özyazıcı ve ark. (2014)'nın bildirdiğine göre, geçmişte yapılan çalışmalarla Türkiye toprakları 1/25000 ölçekli topoğrafik haritalar kullanılarak istikşafi düzeyde haritalanması gerçekleştirilmiştir. Yapılan çalışmayla, 1938 yılında üretilen Amerikan toprak siniflandırma sisteminden yararlanılmış ve elde edilen sonuçlar 1/100000 ölçekli her bir ile ait "İl Arazi Varlığı Raporu" şeklinde yayınlanmıştır (Canpolat, 1981). Bu anlamda; Van ilinin tek veri kaynağı, eski toprak sinıflandırma sistemine göre hazırlanan 1/100000 ölçekli (Anonim, 1987), basılı toprak haritalarıdır. $\mathrm{Bu}$ haritalar yardımıyla toprak derinliği, eğim, erozyon derecesi, drenaj, tuzluluk, alkalilik, taşlılık, kayalılık, arazi kullanım kabiliyet sınıfı, alt sınıfi ve arazi kullanım durumu bilgileri elde edilebilmektedir. Oysa detaylı araştırmalarda bu haritaların kullanımı mümkün olamamaktadır.

Günümüz teknolojileri doğrultusunda toprak etütlerine göre arazilerin gruplandırılıp haritalanması, ülke çapında olduğu gibi Van ili için de önemli sorunlardandır. Coğrafi Bilgi Sistemleri, dijitalleşen dünyada çok farklı bilimsel çalışmalarda kullanım alanı bulmuştur. Bilhassa ortama bağlı, yer ve konum içeren bilginin yönetilmesini içeren konularda kullanıldığı gözlemlenmektedir. Bunun dışında CBS, kaynak yönetim ve planlaması gibi girift analiz içeren durumlarda önemli bir etkinliğe sahiptir (Akbaş ve ark., 2008; Başayiğit ve Şenol, 2008).

Coğrafi Bilgi Sistemleri; her türlü verinin gerçek koordinatlar düzleminde bir veri tabanında toplanması, analizlerin yapılması ve sonuçların görsel şekillerde gösterilmesi maksadiyla oluşturulan bir bilgisayar programıdır (Demirci, 2008; Fitzpatrick ve Maguire, 2000). Toprak Bilgi Sistemleri, toprağın niteliğini harita şeklinde dijital ortamda saklayan ve bunların analizini esas alan sitemlerdir (Lillesand ve Kiefer, 2000; Harmon ve Anderson, 2003). Coğrafi Bilgi Sistemleri ayrıca; karar alma süreçlerinde, model oluşturma, çözümleme, uzaysal algılama niteliğinden dolayı doğruluğu yüksek, güncel bilgilerin üretilmesi ve planlanmasında önemli rol almaktadır (Mitchell, 1999).

$\mathrm{Bu}$ çalışma; topoğrafik haritalar ve (Mülga) Köy Hizmetleri Genel Müdürlüğü (KHGM) tarafindan yapılan Van ili toprak haritalarından, CBS ortamında yapılan analizleri ve sonuçlarını kapsamaktadır.

\section{Materyal ve Yöntem}

Çalışma alanı Van il sınırlarını kapsamaktadır. Türkiye'nin Doğu Anadolu Bölgesi'nde bulunan Van ili, $42^{\circ} 40^{\prime}$ ve $44^{\circ} 30^{\prime}$ doğu boylamları ile $37^{\circ}$ $43^{\prime}$ ve $39^{\circ} 26^{\prime}$ kuzey enlemleri arasındadır. Van ili, Doğu Anadolu Bölgesi'nin Yukarı Murat-Van Bölümü'ndeki Van Gölü kapalı havzası içinde yer almaktadır. İlin kuzeyinde Ağrı ilinin Doğubayazıt, Diyadin ve Hamur ilçeleri, batısında Ağrı ilinin Patnos ilçesi, Bitlis'in Tatvan, Adilcevaz ve Hizan ilçeleri, güneyinde ise Siirt'in Pervari ilçesi, Hakkâri ilinin Beytüşşebap ve Yüksekova ilçeleri bulunmaktadır. Doğusunda ise İran Devleti sınırları yer alır. İl toprakları 19.069 $\mathrm{km}^{2}$ olan yüz ölçümü ile Türkiye topraklarının \% 2.5'ini oluşturur. Van, Türkiye'nin yüz ölçümü bakımından 6. büyük ilidir (Şekil 1). 


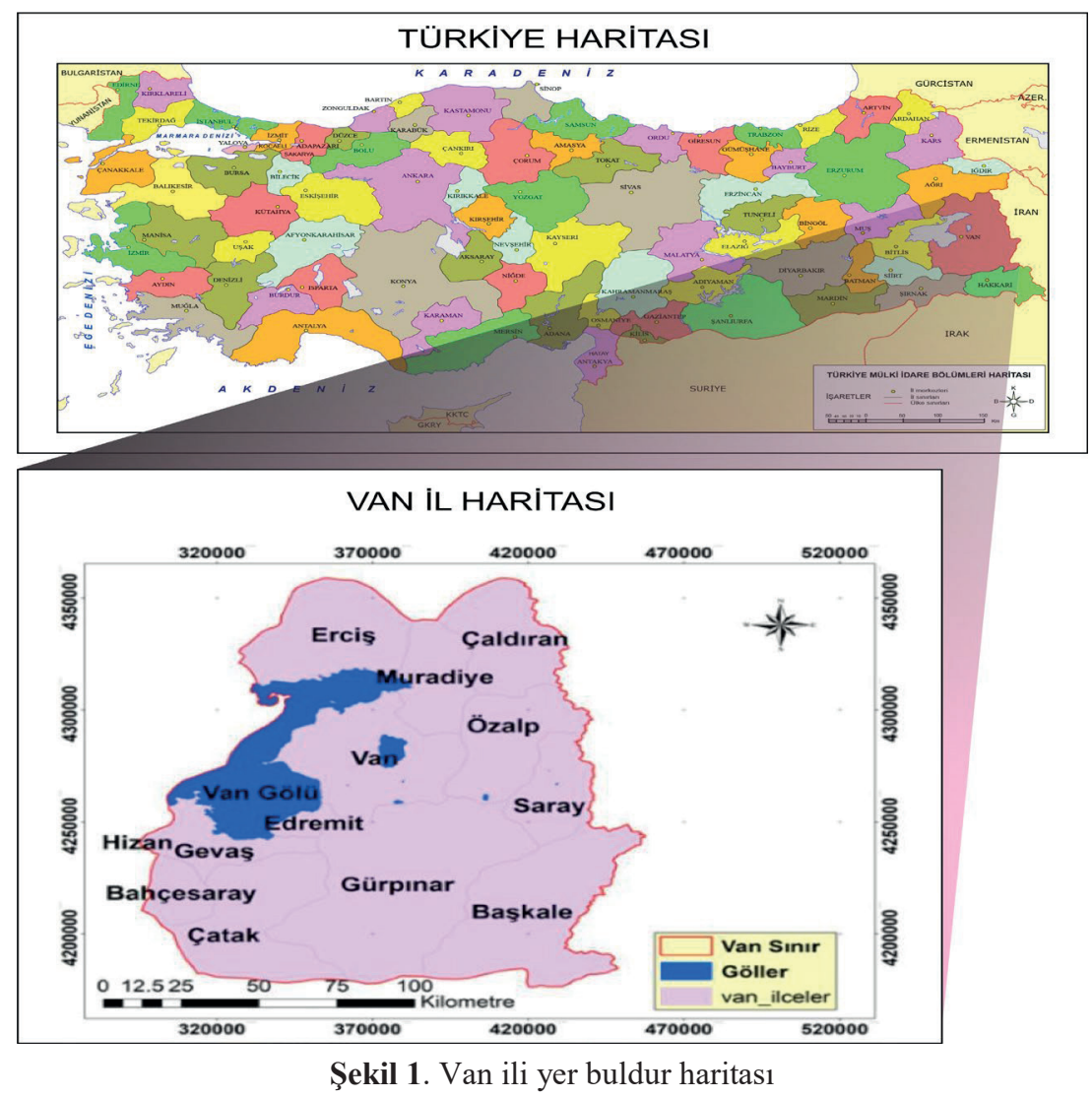

Van ili, Doğu Anadolu Bölgesi'nin volkanik dağlarla kaplı çukur kesiminde bulunan Van Gölü'nün doğu kıyısına $5 \mathrm{~km}$ uzaklıkta çok az meyilli bir arazi üzerine kurulmuştur. Rakım yaklaşık 1725 m'dir. Türkiye'nin en büyük gölü olan Van Gölü yüksek dağların ortasında bir çöküntü durumundadır. Çevredeki yüksek dağlar Van ilinin sınırını oluşturur (Anonim, 2010).

Van ilinde genel olarak karasal iklim görülmektedir. Van gölünün iklimi yumuşatıcı etkisiyle kışlar çok sert geçmemektedir. İlin doğu ve kuzey bölgelerinde kışlar daha sert ve yağışli, güney ve güneybatı bölgelerinde ise 1 lık geçer. Gece ile gündüz arasındaki sıcaklık farkı fazladır (Anonim, 2013). Gece-gündüz sıcaklık değerleri arasındaki farklılık fazladır. Uzun yılların (79 y1llı) iklim verileri incelendiğinde; ilin yıllık ortalama sıcaklığı $9.4{ }^{\circ} \mathrm{C}$, en yüksek ortalama sıcaklık değeri $14.8{ }^{\circ} \mathrm{C}$, en düşük sıcaklık ortalama değeri $3.6{ }^{\circ} \mathrm{C}$ 'dir. Belirlenen maksimum hava sıcaklığı $37.5^{\circ} \mathrm{C}$, en düșük hava sıcaklığ 1 ise -28.7 ${ }^{\circ} \mathrm{C}$ 'dir. İlin yağış verilerine bakıldığında ise ortalama toplam yağış değeri $387 \mathrm{~mm}$ civarındadır (Anonim, 2019). Van ilinin kuzeyi ve doğusunda rakımın yüksek olması nedeniyle, yağış miktarları daha fazladır. Kasım ayı ile Nisan ayı sonuna kadar kar yağışları görülür. Van ili Türkiye'nin en fazla güneș alan illeri arasındadır. Van ilinin adı, Urartu Uygarlığı zamanında "Tuşba" olarak kayıtlarda geçmektedir. Tuşba kelimesinin anlamı "güneşi bol olan” yer anlamına gelmektedir.

Araştırma alanının arazi ve toprak özelliklerinin saptanması için Harita Genel Komutanlığı'nın ürettiği Van iline ait 1:25.000 ölçekli topoğrafik haritalar ile KHGM tarafindan yapılan Van ili toprak haritalarından faydalanılmıştır. Van ili sınırlarını kapsayan, topografik haritalardan da faydalanılarak çalışılan bölgenin muhtelif (eğim, bakı, yükselti) haritaları üretilmiştir (Şekil 2 ve 3).

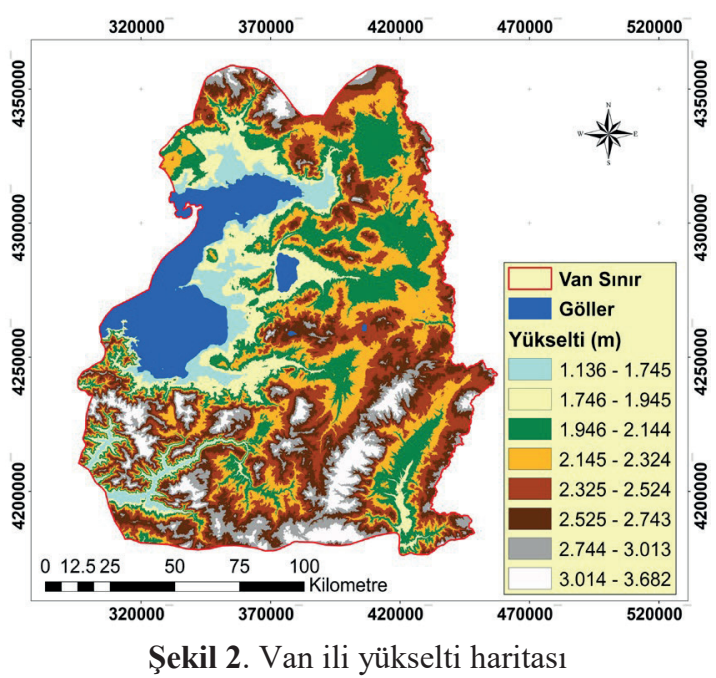




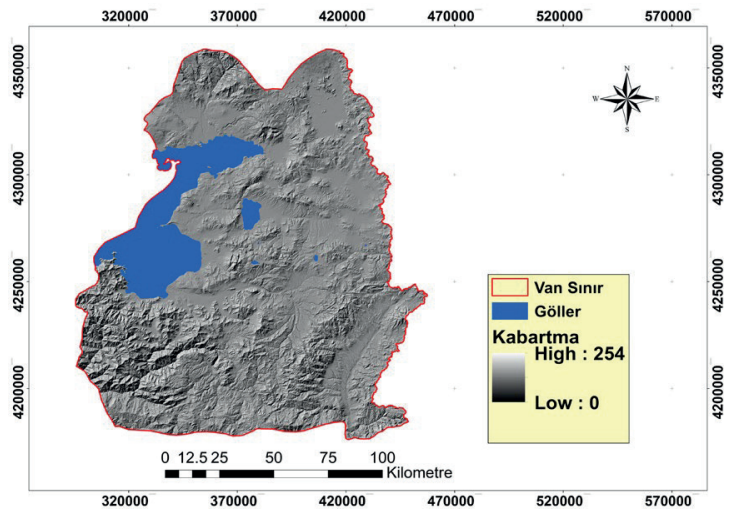

Şekil 3. Van ili kabartma haritası

Çalışmada, KHGM tarafindan oluşturulan Van ili arazilerine ait paftalar CBS ortamında sayısallaştırılmış ve haritalarda yer alan özellikler ile CBS ortamında veri tabanı oluşturulmuştur. Veri tabanından yararlanılarak alana ait erozyon, toprak derinliği, arazi kullanım kabiliyet sınıfları, arazi kullanım haritaları gibi bazı tematik haritalar elde edilmiş, sonrasında alansal ve oransal dağılımları hesaplanmıştır. Elde edilen verilerin işlenmesi ve analizleri için ArcGIS 10.3 Coğrafi Bilgi Sistemleri programı çalışmada kullanılmıştır.

\section{Bulgular ve Tartışma}

\subsection{Van ilinin temel arazi özellikleri}

Toprak oluşumunu etkileyen eğim, arazi örtüsünün durumu, arazi kullanımındaki farklılıklar, toprak sınıfları, erozyonun oluşmasını etkileyen başlica faktördür (Dengiz ve ark., 2013). Van ilinin toplam alanın \% 24.63'ü \% 6'dan düşük eğim değerlerine sahip iken, \% 40.53'ü ise \% 6-30 arasındaki eğim değerlerine sahip olduğu, \% 30’un altında bulunan eğimli alanların ilin \% 64.16'sını kapladığı eğim haritasında görülmektedir (Tablo 1, Şekil 4). Çalışma alanın arazi ve toprak özelliklerini etkileyen en önemli faktörlerden biri olarak, eğim öne çıkmaktadır.

Coğrafi bilgi sistemi içerisinde üç boyutlu analizlerin gerçekleştirilebilmesi için sayısal arazi modeli büyük önem taşır. Bak1, her raster hücresi için ayrı ayrı sayısal arazi modelinden hesaplanır (Özyazıcı ve ark., 2014). Çalışma alanının bakı

Tablo 1. Van ili eğim sınıfları

\begin{tabular}{lcc}
\hline Eğim & Alan (ha) & Oran (\%) \\
\hline $0-2$ & 302.151 & 14.56 \\
$2-6$ & 209.139 & 10.07 \\
$6-12$ & 253.375 & 12.21 \\
$12-20$ & 284.036 & 13.68 \\
$20-30$ & 303.982 & 14.64 \\
$30-45$ & 356.463 & 17.17 \\
$45+$ & 366.754 & 17.67 \\
\hline Toplam & 2.075 .900 & 100.00 \\
\hline
\end{tabular}

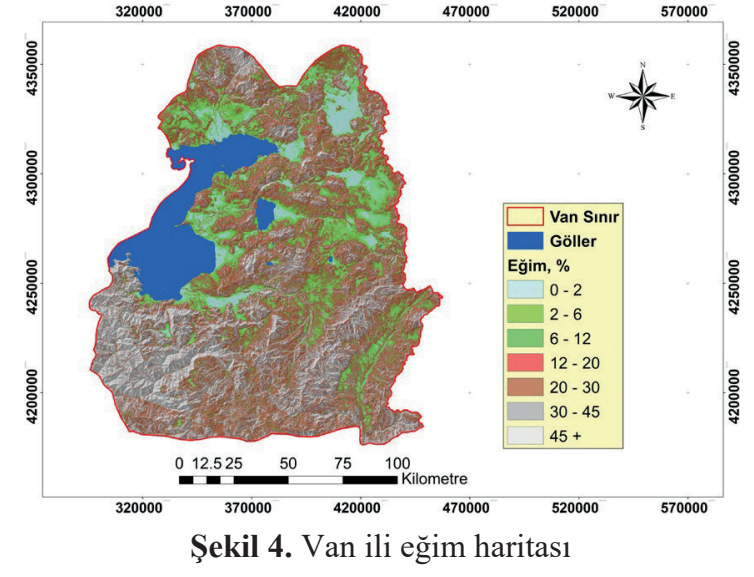

haritasını incelediğimizde, Van ilinin kuzeyinde yer alan Çaldıran, güney doğusunda yer alan Gürpınar, kuzey batısında yer alan Erciş ile Van gölünün kıyı kesimindeki arazilerde düz alanların bulunduğu görülmektedir. $\mathrm{Bu}$ durum gölün yükselmesi ve alçalmasından dolayı gerçekleşmiştir (Tablo 2, Şekil 5).

Tablo 2. Van ili bakı sınıfları

\begin{tabular}{lcc}
\hline Bak1 & Alan (ha) & Oran (\%) \\
\hline 1: Düz & 161.301 & 7.77 \\
2: Kuzey & 116.984 & 5.64 \\
3: Kuzeydoğu & 227.439 & 10.96 \\
4: Doğu & 204.644 & 9.86 \\
5: Güneydoğu & 240.734 & 11.60 \\
6: Güney & 244.814 & 11.79 \\
7: Güneybatı & 254.667 & 12.27 \\
8: Batı & 240.557 & 11.59 \\
9: Kuzeybatı & 263.396 & 12.69 \\
10: Kuzey & 121.363 & 5.85 \\
\hline Toplam & 2.075 .900 & 100.00 \\
\hline
\end{tabular}

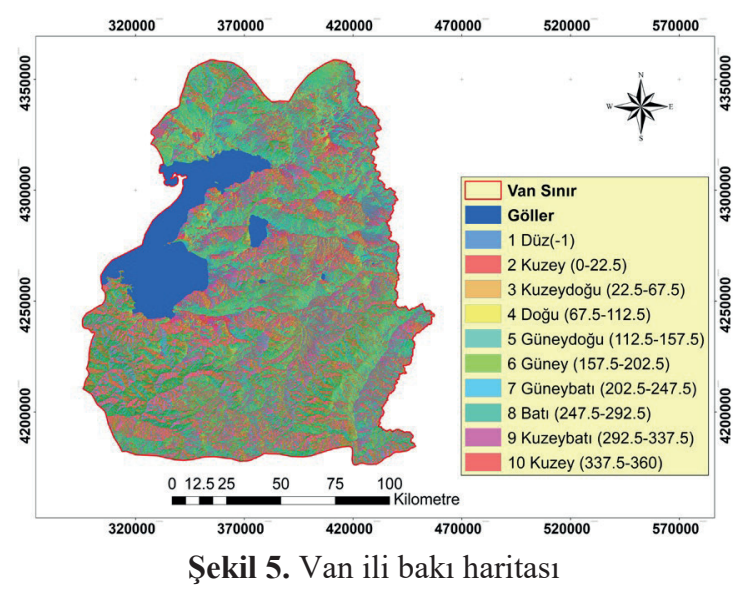

Çalışma alanında toprak oluşum faktörlerinden iklim ve topoğrafyanın etkisiyle ana materyaldeki değişimlerle farklı toprak grupları oluşmasında etkili olmuştur. Van ilinde çoğunlukla görülen büyük toprak grubu, \% 49.21 oraniyla kestane rengi topraklardır. $\mathrm{Bu}$ grubu sirasiyla \% 15.62 
oranıyla kireçsiz kahverengi topraklar ile \% 13.00 oranıyla kahverengi topraklar izlemektedir. Van ilinin kuzey ve güney yüksek kesimlerini bu topraklar kaplamaktadır. Verimi yüksek olan aluviyal topraklar ise \% 3.22'lik bir orana sahiptir. $\mathrm{Bu}$ topraklar çoğunlukla Van Gölü Havzası içerisinde kalan düşük eğimli, düz alanlarda yer almaktadır (Tablo 3, Şekil 6). Çalışma alanında göl kıyılarında yer alan toprakların oluşmasında ve karakter kazanmasında pH'sı yüksek, sodalı bir göl olan Van gölünün etkisi büyüktür.

Tablo 3. Van ili büyük toprak grupları sınıfları

\begin{tabular}{lrc}
\hline Büyük Toprak Grupları & Alan (ha) & Oran (\%) \\
\hline A: Aluviyal & 66.943 & 3.22 \\
B: Kahverengi toprak & 269.807 & 13.00 \\
CE: Kestane renkli toprak & 1.021 .537 & 49.21 \\
K: Koluviyal toprak & 20.931 & 1.01 \\
L: Regosoller & 14.637 & 0.71 \\
M: Kahverengi orman toprağı & 1.030 & 0.05 \\
N: Kireçsiz kahverengi orman & 25.632 & 1.23 \\
toprakları & 268 & 0.01 \\
S: Alüviyal Sahil Bataklıkları & 324.173 & 15.62 \\
U:Kireçsiz Kahve Rengi & & \\
Topraklar & 305.615 & 14.72 \\
GL, YR: Göller ve Yerleşim & & \\
ve diğer araziler & 2.075 .900 & 100.00 \\
\hline Toplam & & \\
\hline
\end{tabular}

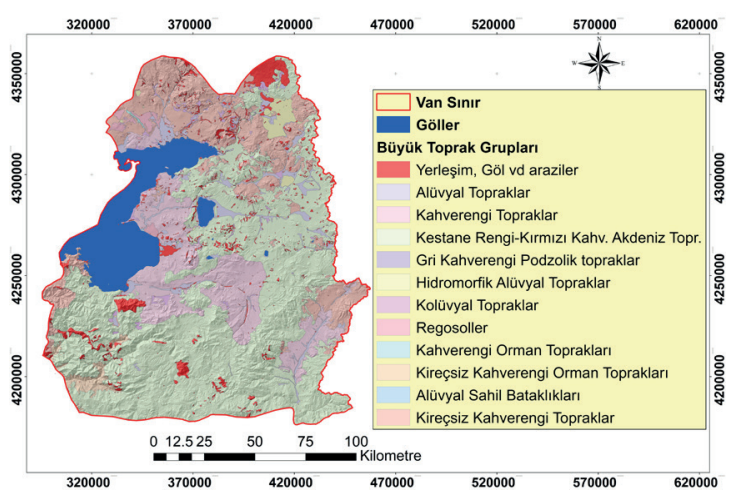

Şekil 6. Van ili büyük toprak grupları haritası

Tablo 4'teki şimdiki arazi kullanımı haritası incelendiğinde, ilin \% 61.03'lük kısmı mera alanı olarak görülmektedir. Kuru tarım yapılan alanlar ise \% 14.55'lik (302115 ha) alanı kapsamaktadır. İlin \% 1.85'lik kısmını ise fundalık arazi teşkil etmekte ve alanı 38422 hektardır. Çayır alanları ise ilin \% 2.87'lik kısmını oluşturmaktadır. Van ilinde küçük oranlarda sulu tarım (\% 4.24), nadassız kuru tarım (\% 0.02), bahçe kuru (\% 0.10) ve bahçe sulu (\% 0.003) tarımı yapılmaktadır (Şekil 7). Topoğrafyanın ve yüksekliğin etkisiyle arazilerin büyük kısmı doğal mera alanları olarak kullanılmaktadır. İl genelinde sulama imkânlarının kısıtlı olması nedeniyle sulu tarım alanları oldukça azdır. Buna bağlı olarak tarımsal kullanım daha çok kuru tarım şeklindedir.

Tablo 4.Van ili şimdiki arazi kullanım sınıfları

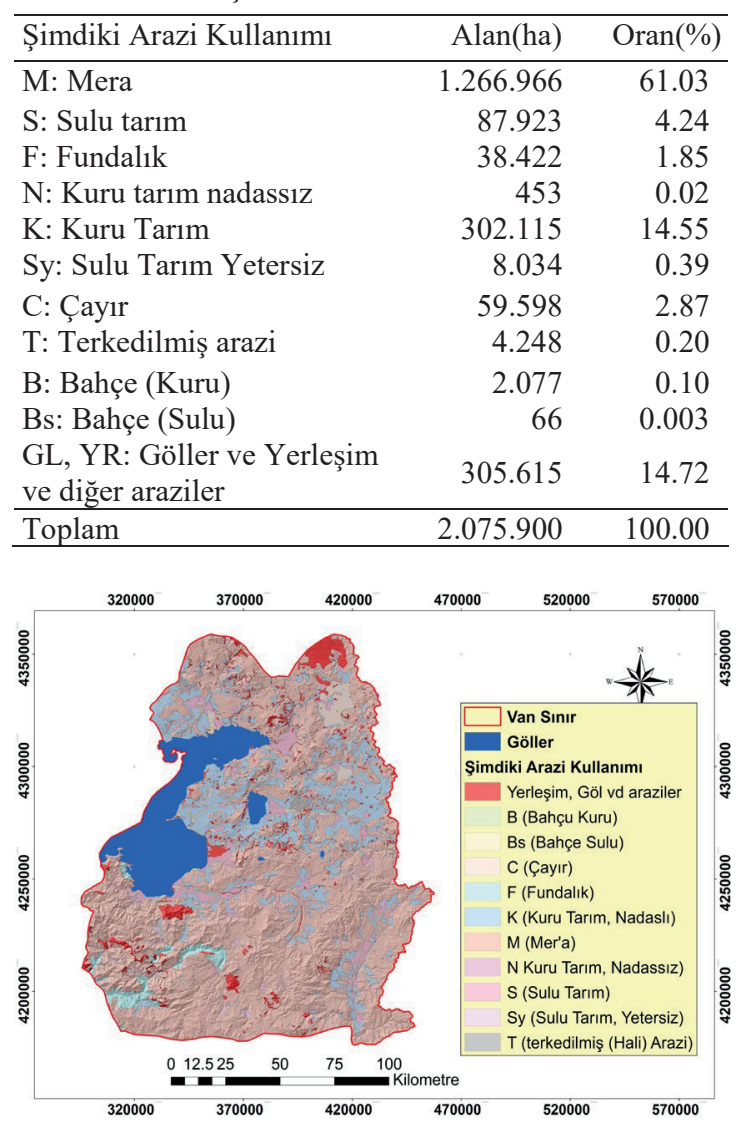

Şekil 7. Van ili şimdiki arazi kullanım haritası

Tablo 5'te verilen erozyon haritası incelendiğinde, Van ilinin \% 32.24'ünde çok şiddetli, \% 23.54'ünde şiddetli erozyon ve $\%$ 21.42'sinde ise orta şiddetli erozyon alanları olduğu görülmektedir. Muhtelif şiddetlerde bulunan erozyon sahalarının toplamı 1602745 hektardır. Hiç veya çok az erozyon sınıfina giren \% 8.07 oranındaki araziler çalışma sahasının farklı yönlerindeki ovalık arazileri kapsamaktadır (Şekil 8). İl genelinde erozyon büyük sorun teşkil etmektedir. Ayrıca eğimi yüksek arazilerde bitki örtüsü varlığının az olması toprak erozyonunu arttırıcı etken olarak görülmektedir.

Tablo 5. Van ili erozyon sinıfları

\begin{tabular}{lcc}
\hline Erozyon sınıfları & Alan (ha) & Oran (\%) \\
\hline 1: Çok az veya yok & 167.540 & 8.07 \\
2: Orta şiddetli & 444.661 & 21.42 \\
3: Şiddetli & 488.760 & 23.54 \\
4: Çok Şiddetli & 669.324 & 32.24 \\
GL. YR: Göller ve Yerleşim & 305.615 & 14.72 \\
ve diğer araziler & & \\
\hline Toplam & 2.075 .900 & 100.00 \\
\hline
\end{tabular}




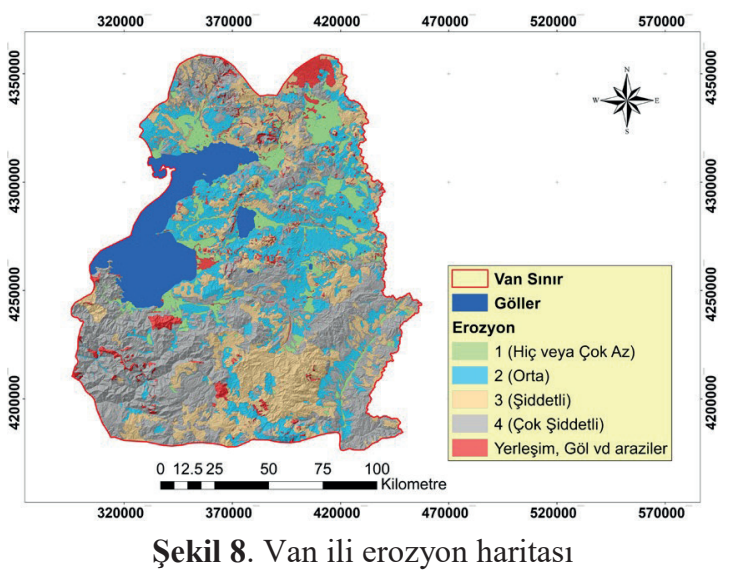

Arazi kullanım kabiliyet sınıfları haritası incelendiğinde; çalışma sahasındaki VII. sınıf arazilerin \% 47.08'lik oranılla 977246 ha alan, VI. sinıf arazilerin ise \% 11.15 'lik oranıyla 231458 ha alan kapladıkları görülmektedir. Tarımsal açıdan kullanılması mümkün olmayan VIII. sınıfı oluşturan çıplak kayalık araziler de \% 4.31'lik oranıyla 89558 ha alan kaplamaktadır. İşlemeli tarım için uygun olan I., II., III. sınıf araziler ise \% 16.39'luk alana sahiptirler (Tablo 6, Şekil 9). İl genelinde eğim yüzdelerinin yüksek olmasından dolayı işlemi tarım yapılan araziler dâhil erozyon için gerekli koruma önlemlerinin alınması gerekmektedir.

Tablo 6.Van ili arazi kullanım kabiliyet sınıfları

\begin{tabular}{lrr}
\hline Arazi Kullanımı & $\begin{array}{c}\text { Alan } \\
\text { Sina })\end{array}$ & \multicolumn{1}{c}{$\begin{array}{c}\text { Oran } \\
(\%)\end{array}$} \\
\hline I & 45.884 & 2.21 \\
II & 111.584 & 5.38 \\
III & 182.713 & 8.80 \\
IV & 206.923 & 9.97 \\
V & 144.31 & 0.70 \\
VI & 231.458 & 11.15 \\
VII & 977.246 & 47.08 \\
VIII & 89.558 & 4.31 \\
GL, YR: Göller ve Yerleşim & 216.103 & 10.41 \\
ve diğer araziler & & \\
\hline Toplam & 2.075 .900 & 100.00 \\
\hline
\end{tabular}

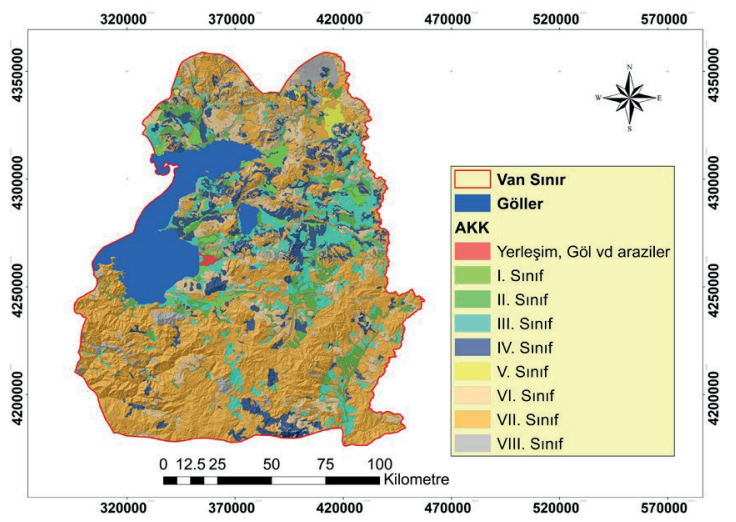

Şekil 9. Van ili arazi kullanım kabiliyeti haritası
Toprak derinlik haritasına bakıldığında; arazilerin \% 27.69'unun orta derin topraklar, \% 16.09'unun da siğ topraklarla kaplı olduğu görülmektedir (Tablo 7, Şekil 10). Topoğrafyanın etkisiyle derin toprakların oranı düşük seviyelerdedir. Van ilinde toprak derinliği, eğim ve buna bağlı olarak erozyon ile ilkim faktörü arazi kullanımını ve bitkisel üretim çeşitliliğini etkileyen en önemli faktörler olarak görülmektedir.

Tablo 7. Van ili toprak derinlik sinıfları

\begin{tabular}{lcc}
\hline Toprak Derinliği $(\mathrm{cm})$ & Alan (ha) & Oran (\%) \\
\hline 0-20 Çok s1 $\breve{g}$ & 158.162 & 7.62 \\
20-50 Sı & 334.028 & 16.09 \\
50-90 Orta Derin & 574.907 & 27.69 \\
90 + Derin & 345.498 & 16.64 \\
Litolozik & 357.690 & 17.23 \\
GL, YR: Göller ve & 305.615 & 14.72 \\
Yerleşim ve diğer araziler & & \\
\hline Toplam & 2.075 .900 & 100.00 \\
\hline
\end{tabular}

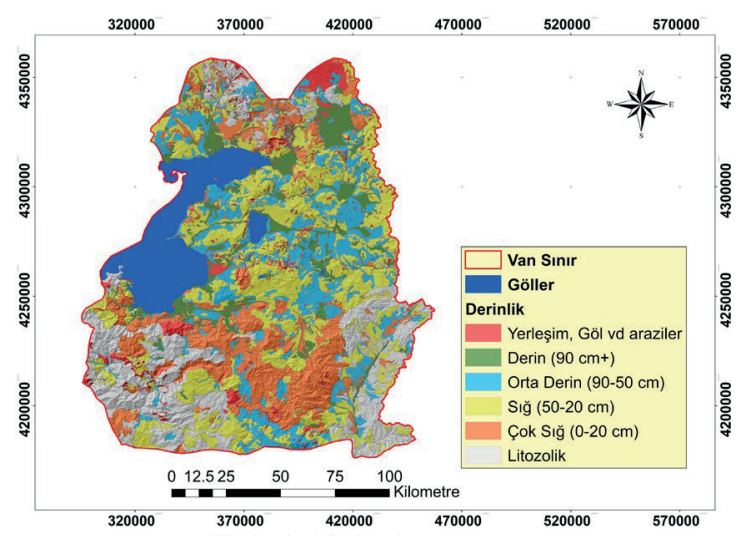

Sekil 10. Van ili derinlik haritas

\subsection{Van ili topraklarının verimlilik özellikleri}

Türkiye toprakları üzerine toprak nitelik ve verimliğinin belirlenmesi için yapılan en nitelikli araştırma, KHGM tarafından yapılan "Türkiye Topraklarının Verimlilik Envanteri Projesi (TOVEP)"dir. Yapılmış olan “TOVEP" projesiyle Van genelinde toprakların esas olan besin elementi kapsamları, organik madde, $\mathrm{pH}$, kireç içerikleri ile tekstür sınıfları araştırılmıştır. Elde edilen sonuçlar 1/100000 ile ölçeklendirilmiş haritalarda yayınlanmıştır. Van iline ait toprak verimlilik özelliklerini kapsayan bu rapor (Anonim, 1984) dışında veri bulunmamaktadır. Anonim (1984)'e göre, Van ili tarım topraklarının; suyla saturasyon yüzdesine göre, toprak bünyesi \% 8.8'i kumlu, \% 3.3'ü killi, \% 65.0 tınlı, \% 22.5'i killi-tınlıdır. İl topraklarının \% 3.4'ü asit, \% 50.6's1 alkali ve $\%$ 45.0'i nötr reaksiyonlu olup, toprakların $\%$ 84.5'i tuzsuzdur. Van ilinde tarım yapılan topraklarının \% 26.1'i az kireçli, \% 22.8'i orta kireçli, \% 24.2'si kireçli, \% 13.4'ü fazla kireçli ve 13.5'i çok fazla kireçlidir. Aynı araştırma 
kapsamında alınan 4276 toprak örneğinin analiz sonuçlarına göre, Van ili tarım topraklarının; organik madde içeriği incelenen örneklerin \% 20.8'inde çok az, \% 26.9'unda orta, \% 7.6'sında iyi ve \% 11.3 'ünde ise yüksek; alınabilir fosforun $\left(\mathrm{P}_{2} \mathrm{O}_{5}\right) \quad \%$ 48.7'sinde çok az, \% 37'sinde az, $\%$ 8.1'inde orta, \% 4.3'ü yüksek ve \% 1.9'unda çok yüksek düzeyde olduğu rapor edilmiştir. Tarımsal kullanımı olan toprakların bütününde alınabilir potasyumun $\left(\mathrm{K}_{2} \mathrm{O}\right)$ ise \% 98.1'inde orta ve yeterli miktarda olduğu tespit edilmiştir (Anonim, 1984).

\section{Sonuçlar}

Çalışmada Van ilinin arazi ve toprak verileri topoğrafya özellikleri ile birlikte CBS ortamında analiz edilmiştir. Topoğrafyası incelenen bölgenin, yükseklik bilgisi ile birlikte analiz edilmesi ile daha kapsamlı sonuçların elde edildiği düşünülmektedir. Sonuçlara göre bazı arazilerin tarım yapılabilir nitelikte olmasına karşın, topoğrafya açısından uygun olmadığı ortaya çıkmıştır. Tarım amaçlı kullanılan araziler de eğimin yüksek olması, toprak erozyonuna neden olacağı için sakıncalı bir durumdur. Çalışma ile arazilerin kullanım kabiliyeti, eğim ve yüksekliği bakımından tarıma uygun olup olmadığı daha net açığa çıkmıştır. Ayrıca Van ilinde yer alan büyük toprak gruplarının ve arazi kullanım türlerinin yer aldığ 1 bölgeler ve oranları ortaya konmuştur. Elde edilen sonuçlar ile Van ilinin, topoğrafya koşullarından dolayı, işlenebilir tarıma yatkın olan arazilerinin çok az olduğu ve potansiyel olarak toprak erozyonuyla karşı karşıya olduğu saptanmıştır. Tarımsal üretim yapılan eğimli arazilerin büyük bir kısmında özel toprak koruma önlemlerine gerekli olduğu söylenebilir. Var olan toprak ve arazi özelliklerine ait verilerin CBS ortamında analizleri, toprakların sürdürülebilir ve etkin bir şekilde kullanımına yardımcı olacaktır.

\section{Kaynaklar}

Akbaş, F., Ünlükara, A., Kurunç, A., İpek, U., Yıldız, H., 2008. Tokat- Kazova'da taban suyu gözlemlerinin CBS yöntemleriyle yapılması ve yorumlanması. Sulama ve Tuzlanma Konferansı, 12-13 Haziran, Şanlıurfa, s.1-12.

Akgül, M., Başayiğit, L., 2005. Süleyman Demirel Üniversitesi çiftlik arazisinin detaylı toprak etüdü ve haritalanmas1. Süleyman Demirel Üniversitesi Fen Bilimleri Enstitüsü Dergisi, 9(3): 1-10.

Anonim, 1984. Van İli Verimlilik Envanteri ve Gübre İhtiyaç Raporu. T.C. Tarım Orman ve Köy İşleri Bakanlığı Toprak Su Genel Müdürlüğ̈̈ Yayınları, TOVEP Yayin No: 31, Ankara.

Anonim, 1987. Van İli Verimlilik Envanteri ve Gübre İhtiyaç Raporu. T.C. Tarım Orman ve Köy İşleri
Bakanlığı Toprak Su Genel Müdürlüğü Yayınları, TOVEP Yayın No: 46, Ankara.

Anonim, 2010. Van Tarım İl Brifing Raporu. Van Tarım İl Müdürlüğü Yayını, Van.

Anonim, 2013. Van Tarım İl Brifing Raporu. Van Tarım İl Müdürlüğü Yayını, Van.

Anonim, 2019. Van İline Ait İstatistiki Veriler. T.C. Tarım ve Orman Bakanlığı Meteoroloji Genel Müdürlüğü. (https://www.mgm.gov.tr/genel/adres ler.aspx), (Erişim tarihi: 21.01.2019).

Başayiğit, L., Şenol, H., 2008. Meyve yetiştirme potansiyeli yüksek alanların coğrafi bilgi sistemleri ortamında belirlenebildiği ve uzaktan algilama metodu ile kontrolü. Süleyman Demirel Üniversitesi Ziraat Fakültesi Dergisi, 3(1): 1-8.

Canpolat, O., 1981. Türkiye topraklarının tarımsal kullanıma uygunluk bakımından incelenmesi. DSi, Toprak ve Su Kaynaklarının Geliştirilmesi Konferansl Bildirileri, Ankara, Cilt 1, s: 60-87.

Demirci, A., 2008. Öğretmenler için CBS: Coğrafi Bilgi Sistemleri (GIS for Teachers) İstanbul: Fatih Üniversitesi Yayınları, İstanbul, Yayın no: 41.

Dengiz, O., Sağlam, M., Özaytekin, H.H., Baskan, O. 2013. Weathering rates and some physico-chemical characteristics of soils developed on a calcic toposequences. Carpathian Journal of Earth and Environmental Sciences, 8(2): 13-24.

Dengiz, O., Sarığlu, F.E., 2011a. Samsun ili bazı arazi özellikleri ve arazi kullanım durumlarının topoğrafik özellikleri ile birlikte CBS analizleri. Ege Üniversitesi Ziraat Fakültesi Dergisi, 48(1): 55-60.

Dengiz, O., Sarığlu, F.E., 2011b. Samsun ilinin potansiyel tarım alanlarının genel dağılımları ve toprak etüd ve haritalama çalışmalarının önemi. Anadolu Tarım Bilimleri Dergisi, 26(3): 241-253.

Fitzpatrick, C., Maguire, D.J., 2000. GIS in Schools: Infrastructure, Methodology and Role. In D.R. Green (Ed.), GIS: A sourcebook for schools, Taylor \& Francis, pp. 61-62.

Harmon, J.E., Anderson, S.J., 2003. The design and implementation of geographic information systems. John Wiley\&Sons. Inc. Hoboken, New Jersey.

Lillesand, T.M., Kiefer R.W., 2000. Remote Sensing and Image Interpretation $4^{\text {th }}$ Ed. New York USA, John Wiley \& Sons Inc.

Mitchell, A., 1999. GIS Analysis, Volume 1, California, ESRI.

Özyazıcı, M.A., Dengiz, O., İmamoğlu, A., 2014. Siirt ili bazı arazi ve toprak özelliklerinin coğrafi bilgi sistem analizleriyle değerlendirilmesi. Türkiye Tarımsal Araştırmalar Dergisi, 1(2): 128-137.

Özyazıcı, M.A., Dengiz, O., Aydoğan, M., Bayraklı, B., Kesim, E., Urla, Ö., Yıldız, H., Ünal, E., 2015. Orta ve Doğu Karadeniz Bölgesi tarım topraklarının bazı makro ve mikro bitki besin maddesi konsantrasyonları ve ters mesafe ağırlık yöntemi (IDW) ile haritalanması. Artvin Çoruh Üniversitesi Orman Fakültesi Dergisi, 16(2): 187-202.

Özyazıcı, M.A., Dengiz, O., Aydoğan, M., Bayraklı, B., Kesim, E., Urla, Ö., Yıldız, H., Ünal, E., 2016. Orta ve Doğu Karadeniz Bölgesi tarım topraklarının temel verimlilik düzeyleri ve alansal dağılımları. Anadolu Tarım Bilimleri Dergisi, 31(1): 136-148. 